\title{
ASSESSMENT OF THE EFFECT OF CEMENT INDUSTRY EFFLUENT DISCHARGE ON WATER QUALITY OF NGO RIVER IN BENUE, NIGERIA
}

\author{
T. A. Aga ${ }^{1}$, C. C. Anyadike ${ }^{2,}{ }^{*}$, C. C. Mbajiorgu ${ }^{3}$ and V. Ogwo ${ }^{4}$ \\ 1, DePt Of Agric. ENGR'G Services, Min. Of Agric. \& NATURAl ReS., MAKURdi, BeNUE STATE, NIGERIA \\ 2, 3, 4, DePT OF AGRIC. \& BiORESOURCES ENGR'G, UNIVERSITY OF NigERIA, NSUKKA, ENUGU STATE, NIGERIA \\ Email addresses: ${ }^{1}$ agatitus33@gmail.com, ${ }^{2}$ chineneye.anyadike@unn.edu.ng, \\ 3 costaintine.mbajiorgu@unn.edu.ng, 4 vintus.ogwo@unn.edu.ng
}

\begin{abstract}
Ngo River in Gboko, Benue State, Nigeria which serves as a source of water for domestic and agricultural purposes for the agrarian community receives effluent from Dangote Cement factory. Physicochemical analysis of the effluent outfall and water samples collected along $15 \mathrm{~km}$ of the river stretch were carried out in dry and wet seasons respectively. The results obtained were compared to FEPA, WHO and NESREA Standards. For effluent outfall, Temperature, TDS, pH, EC, $B O D, C O D$, sulphate and chloride, total hardness, calcium and magnesium, were found to be within the FEPA standards, while TSS, turbidity, and nitrate, were above the standards. Along $15 \mathrm{~km}$ study reach, mean temperature range of $32.4^{\circ} \mathrm{C}$ to $29.0^{\circ} \mathrm{C}$, a TSS of $224 \mathrm{mg} / \mathrm{l}$ to $218 \mathrm{mg} / \mathrm{l}$, a turbidity of $45 \mathrm{NTU}$ to $42 \mathrm{NTU}$, and DO of $1.6 \mathrm{mg} / \mathrm{l}$ to $1.2 \mathrm{mg} / \mathrm{l}$ were obtain during the dry season, while mean temperature range of $36.8^{\circ} \mathrm{C}$ to $36.6^{\circ} \mathrm{C}$, a TSS of $255 \mathrm{mg} / \mathrm{l}$ to $252 \mathrm{mg} / \mathrm{l}$, turbidity of $176 \mathrm{NTU}$ to 168 NTU, and DO $2.8 \mathrm{mg} / \mathrm{l}$ to $2.6 \mathrm{mg} / \mathrm{l}$ were obtained during the wet seasons. These results were above WHO and NESREA temperature (25ㅇ drinking water), TSS (30 mg/l domestic and $100 \mathrm{mg} / \mathrm{I}$ agriculture) water use, $5 \mathrm{NTU}$ turbidity, and $5 \mathrm{mg} / \mathrm{l}$ to $7.5 \mathrm{mg} / \mathrm{l}$ DO standards. The effluent is relatively treated and effects such as aquatic depletion in the environment, decreased soil pore size and decreased permeability in the use of the water for irrigation, and water related diseases are not ruled out.
\end{abstract}

Keywords: Cement industry, Effluent discharge, Water quality, Ngo River.

\section{INTRODUCTION}

The industries, including the cement production sector in Nigeria are playing vital roles in the economic development of the nation. However, the by-products in form of effluent and gaseous waste from the industries are also increasing as production output increases. It was pointed out in [1] that industrial effluent consists of toxic and poisonous mixtures of dissolved solids and suspended solids in varying proportions. These unpleasant and dangerous substances consisting of inorganic and organic components $[2,3]$ are discharged into the environment, including rivers and streams. The direct discharge of industrial effluent into open water bodies in an arbitrary manner without prior assessment of the effect on human, aquatic animals and plants lives, is a growing environmental problem in our modern society, especially Nigeria.

The major pollutant from cement industries is particulates produced in the rotary kiln, and from crushing and grinding, blending, moving material to silos and packaging. Cleaning kiln inner surface to remove piled emission, generates effluents that are composed of waste heat, dissolved solids (potassium and sodium hydroxide, chlorides and sulphate), suspended solids (calcium carbonate) and processed water. These effluents which are discharged into

\footnotetext{
* Corresponding author, tel: +234-803-874- 1426
} 
water bodies, have great possibility of deteriorating the water bodies [4].

The water bodies in which these effluents are discharged serve most times as sources of water for domestic, agricultural and industrial purposes. Hence, the assessment of the water quality of these water bodies are very important since the water demand for these purposes consequently have a close relationship with water availability and economic development of a nation $[5,6]$. Furthermore, the use of water is sometimes restrained by its poor quality which makes it unhealthy for a particular use [7]. Successful management of water resources in Nigeria, and control of water based and water borne diseases require quality assessment of the water bodies. In view of this, [8] assessed the impact of effluent from Obajana Cement factory discharged into Onyi River in Kogi State, and reported the river as being slightly polluted. In 2008, [9] study on heavy metals in sediment of some inland waters adjacent to Benue Cement company, reported that the surface waters appears to have suffered adverse impact from the cement company and therefore not suitable for human consumption. A similar study by [10] on physicochemical characteristics of Ngo River around Dangote cement complex found the values of Temperature, $\mathrm{pH}$, Total Dissolved solids (TDS), Nitrate $\left(\mathrm{NO}_{3}^{-}\right)$, Calcium $(\mathrm{Ca}+)$, Phosphate $(\mathrm{P})$, Chemical Oxygen Demand (COD), Zinc (Zn), Cadmium (Cd), iron ( $\mathrm{Fe})$, lead (pb), chromium ( $\mathrm{Cr})$, and Nickel $(\mathrm{Ni})$ to be in excess of WHO and National

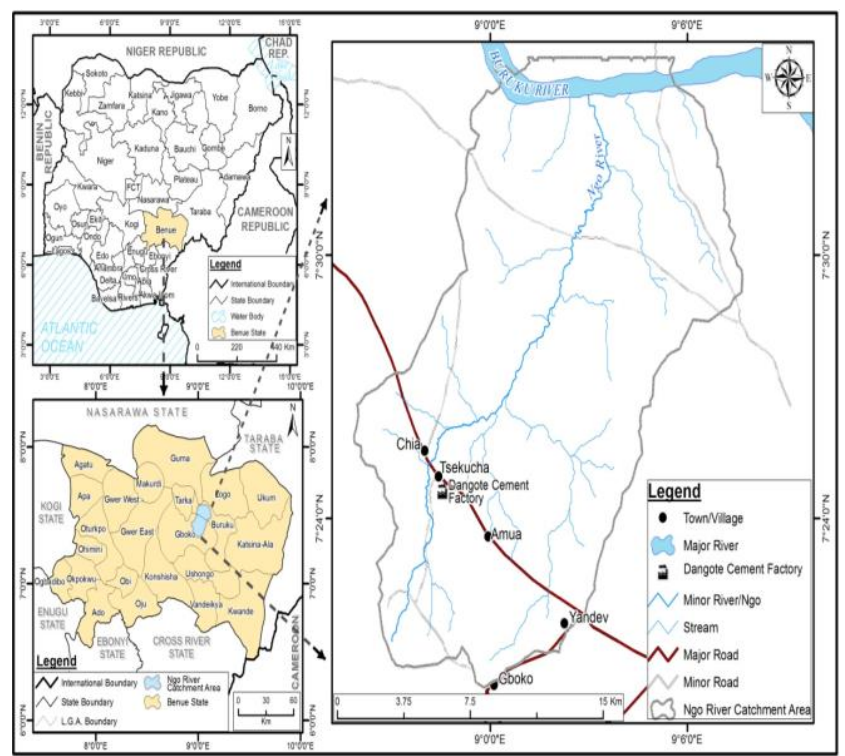

Figure 1: The Ngo River Catchment and its location
Agency for Food and Drugs Administration Control standards.

This Ngo River in Tsekucha, Mbayion, Gboko local government area, Benue State (see Figure 1), is situated in the north of Benue State between latitudes $7^{\circ} 08^{\prime}$ and $7^{0} 31^{\prime} \mathrm{N}$ of the equator and longitudes $8^{0} 37^{\prime}$ and $9^{0} 10^{\prime} \mathrm{E}$ of the Greenwich Meridian [10]. The river; a source of domestic and agriculture water for the surrounding community still receives effluent from Dangote cement factory. The effluent outfall and mixing point is shown in Plate 1. Considering the use of this water body there is a need to assess the effect of the effluent outfall on water quality of the river after a decade of [10] findings. This study therefore assessed the effects of the effluent on Ngo river water quality.

\section{MATERIALS AND METHOD}

\subsection{Water Sampling and Analysis}

The sampling points were located based on accessibility to site observation. Global Positioning System (GPS) was used to determine the locations and elevations of the effluent outfall mixing point and six (6) selected sampling locations along $15 \mathrm{~km}$ of the river reach. The sampling locations were designated as $1,2,3,4,5$ and 6 , respectively. The geographical coordinates and the elevations of selected locations, determined by hand held Garmin GPS60 are shown in Table 1 and Figure 2. Three sampling points of $5 \mathrm{~m}$ apart were marked out at each of the six (6) sampling location for water samples analysis.

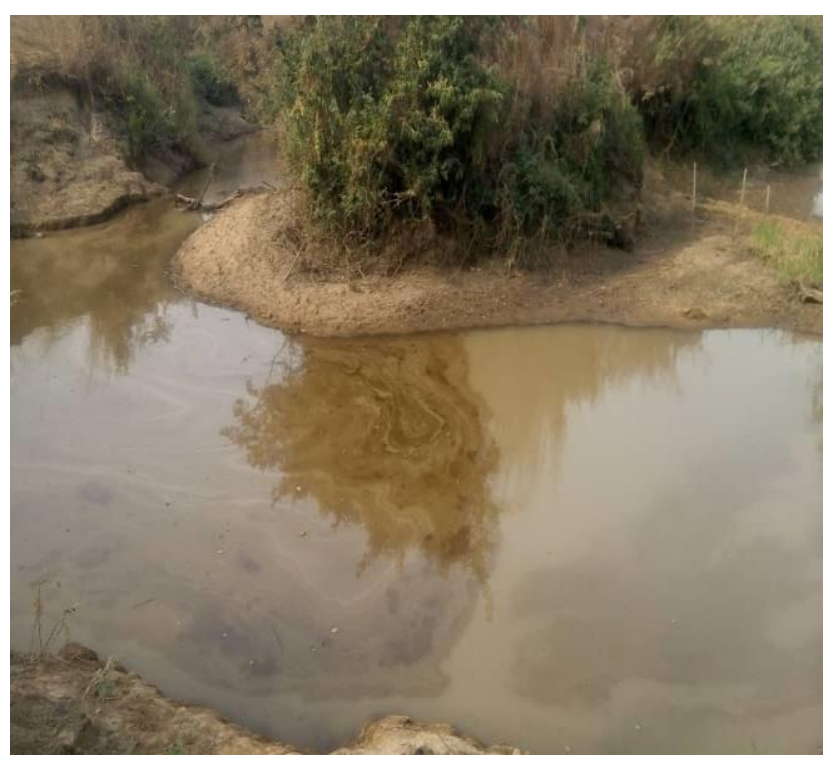

Plate 1: Effluent outfall and mixing point along Ngo River 
Table 1: Coordinates and Elevation of Sampling Points (GPS)

\begin{tabular}{|c|c|c|c|c|}
\hline \multirow{2}{*}{$\begin{array}{l}\text { Sampling } \\
\text { Point }\end{array}$} & \multicolumn{2}{|c|}{ GPS Coordinate Point } & \multirow{2}{*}{$\begin{array}{l}\text { Elevation } \\
(\mathrm{m})\end{array}$} & \multirow{2}{*}{ Remarks } \\
\hline & Latitude & Longitude & & \\
\hline $\begin{array}{l}\text { Effluent } \\
\text { discharge } \\
\text { point }\end{array}$ & $07^{\circ} 24^{\prime} 45^{\prime \prime}$ & $08^{\circ} 58^{\prime} 17^{\prime \prime}$ & 145 & $\begin{array}{l}\text { The sampling point was at } 1 \mathrm{~km} \text { from the head water } \\
\text { boundary, within the first reach of the river segment. } \\
\text { The bed slope was } 0.00085 \text {. } \\
\text { Ngo River upstream before effluent discharge point, } 0\end{array}$ \\
\hline 1 & $07^{\circ} 24^{\prime} 49^{\prime \prime}$ & $08^{\circ} 58^{\prime} 15^{\prime \prime}$ & 141 & $\begin{array}{l}\mathrm{km} \text { on the headwater boundary at river bed slope of } \\
0.00075\end{array}$ \\
\hline 2 & $07^{\circ} 24^{\prime} 56^{\prime \prime}$ & $08^{\circ} 58^{\prime} 09^{\prime \prime}$ & 138 & $\begin{array}{l}\text { Ngo River downstream after effluent discharge point; at } \\
4 \mathrm{~km} \text { from the head water boundary of the study } \\
\text { segment. The river bed slope was } 0.00050\end{array}$ \\
\hline 3 & $07^{\circ} 25^{\prime} 15^{\prime \prime}$ & $08^{\circ} 58^{\prime} 09^{\prime \prime}$ & 136 & $\begin{array}{l}\text { Ngo River downstream (before Ishudugh Village); } \\
\text { located at } 8 \mathrm{Km} \text { along the river shoreline, the bed slope } \\
\text { was } 0.0083\end{array}$ \\
\hline 4 & $07^{\circ} 27^{\prime} 57^{\prime \prime}$ & $09^{\circ} 01^{\prime} 10^{\prime \prime}$ & 111 & $\begin{array}{l}\text { Ngo River downstream; (at Ishudugh Village) about } 11 \\
\text { km along the river shoreline. The bed slope was } 0.0066 \\
\text { Ngo River downstream (before Kpe Ngo) located at } 13\end{array}$ \\
\hline 5 & $07^{\circ} 30^{\prime} 23^{\prime \prime}$ & $09^{\circ} 02^{\prime} 36^{\prime \prime}$ & 91 & $\begin{array}{l}\mathrm{km} \text { from the head water boundary of the river. The river } \\
\text { bed slope was } 0.007\end{array}$ \\
\hline 6 & $07^{\circ} 33^{\prime} 38^{\prime \prime}$ & $09^{\circ} 03^{\prime} 00^{\prime \prime}$ & 84 & $\begin{array}{l}\text { Ngo River downstream (at Kpe Ngo) located at Km } 15 \\
\text { from the head water boundary of the river. River bed } \\
\text { slope was } 0.007\end{array}$ \\
\hline
\end{tabular}

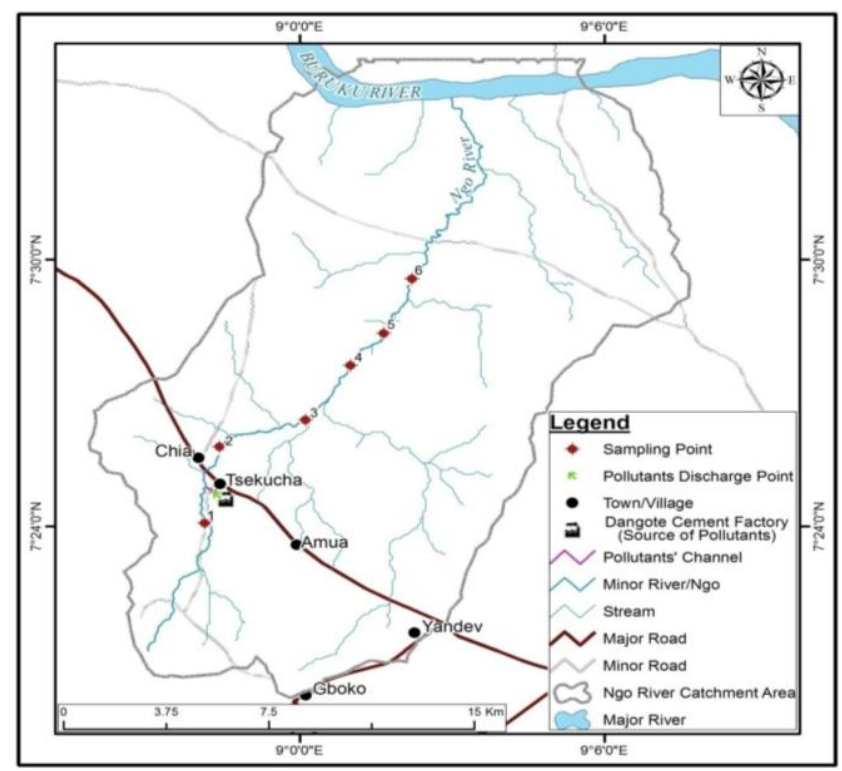

Figure 2: Map of Ngo River Catchment Area and Sampling Points

Grab samples were obtained from the effluent outfall and the marked eighteen (18) sampling points for a period of 15 days in December, 2017 and July, 2018 respectively, at a depth of $20 \mathrm{~cm}$ from the six (6) selected locations for water quality analysis. Plastic bottles of 0.5 liter volume used to obtain the water samples from the 18 sampling points, were washed with the river water prior to fetching the samples. The bottle flange was kept away from contact to prevent contamination of grab samples. Water quality parameters namely temperature, total dissolved solids, pH, electrical conductivity (EC), and dissolved oxygen (DO) were measured in-situ using Hanna model of digital thermometer, pH meter, TDS meter and JPB607 digital DO meter respectively. While grab samples; for analysis of total suspended solids (TSS), turbidity, biochemical oxygen demand (BOD), total phosphate (TP), nitrate, chemical oxygen demand, sulphate $\left(\mathrm{SO}_{4}{ }^{2}\right)$ and chloride $\left(\mathrm{CL}^{-}\right)$total hardness, calcium and magnesium, were kept in $4^{\circ} \mathrm{C}$ ice chamber and transported to Benue State Water Board laboratory, Makurdi. The analysis were carried out using standard procedures of [11]. An average of the three (3) sampled results from each designated locations were taken and compared with $[12,13$, and 14] standards, to ascertain the effect of the effluent along the $15 \mathrm{~km}$ study reach of the river.

\section{RESULTS AND DISCUSSION}

\subsection{Physicochemical Characteristics of Effluent}

The result of physicochemical analysis of effluent outfall presented in Table 2, showed $\mathrm{pH}$, temperature, $\mathrm{TDS}, \mathrm{BOD}, \mathrm{COD}, \mathrm{SO}_{4}{ }^{2-}, \mathrm{CL}^{-} \cdot \mathrm{Ca}^{2+}$, magnesium and total hardness to be within [15] 
standards, while TSS, turbidity, DO, nitrate, for both seasons were observed to exceed the permissible limit of [15]. Hence, the effluent is relatively treated. The obtained result compared to [8] was observed to be better treated. However, there is a need to address the high TSS, turbidity and low DO, as effects such as reduction of sunlight penetration which invariably affect food supplies and growth of aquatic organisms [16], the acceleration of high number of foreign micro biota [17] with its resultant effect on DO, and other negative environmental health impact might be experienced in Ngo river.

\subsection{Physicochemical characteristics of $\mathbf{N g o}$ River}

Water quality is evaluated relative to the requirement for its intended use, and Ngo River serves both domestic and agricultural purposes for the agrarian community. In assessing the effect of the effluent outfall on water quality across the $15 \mathrm{~km}$ of the river study reach, the physicochemical analysis results of location 1(upstream before the effluent out) and location 2 (downstream; after the effluent out) were compared to $[12,14]$ standards and subjected to a ttest analyses at probability levels of 0.01 and 0.05 . The result showed a significant difference at both probability levels of 0.01 and 0.05 . This confirms that the changes observed at the downstream are as a result of the effluent outfall from Dangote cement factory. The physicochemical analysis results from location 2 to location 6 showed mean range of $\mathrm{pH}$ ( 8.4 to 7.8$)$, EC ( $98 \mu \mathrm{s} / \mathrm{cm}$ to $88 \mu \mathrm{s} / \mathrm{cm})$, TDS (98 $\mathrm{mg} / \mathrm{l}$ to $88 \mathrm{mg} / \mathrm{l}), \mathrm{BOD}(0.8 \mathrm{mg} / \mathrm{l}$ to $0.6 \mathrm{mg} / \mathrm{l})$, nitrate $(21.8 \mathrm{mg} / \mathrm{l}$ to $18.0 \mathrm{mg} / \mathrm{l}), \operatorname{COD}(1.6 \mathrm{mg} / \mathrm{l}$ to $1.3 \mathrm{mg} / \mathrm{l})$, sulphate $(62 \mathrm{mg} / \mathrm{l}$ to $56 \mathrm{mg} / \mathrm{l})$ chloride $(70 \mathrm{mg} / \mathrm{l}$ to $35.5 \mathrm{mg} / \mathrm{l})$ and calcium (60 mg/l to $40 \mathrm{mg} / \mathrm{l})$ for dry season, to be within [12 and 14] standards of $\mathrm{pH}(6.5$ to 8.5$)$, TDS $(<600 \mathrm{mg} / \mathrm{l}), \mathrm{BOD}(6.0 \mathrm{mg} / \mathrm{l})$, nitrate $(50 \mathrm{mg} / \mathrm{l})$, COD $(30 \mathrm{mg} / \mathrm{l})$, sulphate $(500 \mathrm{mg} / \mathrm{l})$, chloride $(350 \mathrm{mg} / \mathrm{l})$ and calcium $(180 \mathrm{mg} / \mathrm{l})$. The wet season results showed similar decreasing trend along the $15 \mathrm{~km}$ study reach though the results were higher compared to the dry season, suggesting input from runoff. Temperature mean range of $32.4^{\circ} \mathrm{C}$ to $29.0^{\circ} \mathrm{C}$ and $36.8^{\circ} \mathrm{C}$ to $36.6^{\circ} \mathrm{C}$ for both seasons were above $25^{\circ} \mathrm{C}$ standards for drinking water. TSS mean range of $224 \mathrm{mg} / \mathrm{l}$ to $218 \mathrm{mg} / \mathrm{l}$ and $255 \mathrm{mg} / \mathrm{l}$ to $252 \mathrm{mg} / \mathrm{l}$ for both seasons, were above $(30 \mathrm{mg} / \mathrm{l})$ domestic and $(100 \mathrm{mg} / \mathrm{l})$ agriculture recommended standards. Hence, the possibility of aquatic depletion in the environment, decreased soil pore size and decreased permeability in the use of the water for irrigation, may not be ruled out. Turbidity mean range of 45 NTU to 42 NTU (dry season) and 176 NTU to 168 NTU (wet season), observed along the river stretch may also affect the fishery and water supply use of the Ngo River as it was above the 5 NTU recommended standards. The obtained results were also observed to be better than [10] study on the river a decade ago. Further, a good water body has DO of more than $5 \mathrm{mg} / \mathrm{l}$ to $7.5 \mathrm{mg} / \mathrm{l}$ [12 and 14$]$, however the results of the analysis showed the river DO of $1.6 \mathrm{mg} / \mathrm{l}$ to 1.2 $\mathrm{mg} / \mathrm{l}$ and $2.8 \mathrm{mg} / \mathrm{l}$ to $2.6 \mathrm{mg} / \mathrm{l}$ for both season, will affect the growth of aquatic plants and other organisms, and other uses of the river.

The water quality of Ngo River was observed to have varied with the sampling periods and locations along the river stretch. Results of some of the physicochemical analysis are represented graphically in Figure $2-9$. The observed seasonal variation agreed with [8] study on Onyi River. The variation observed in wet season can be attributed to the nonpoint sources of pollution from runoff that washed pollutant from the adjacent land within the catchment area into the river channel.

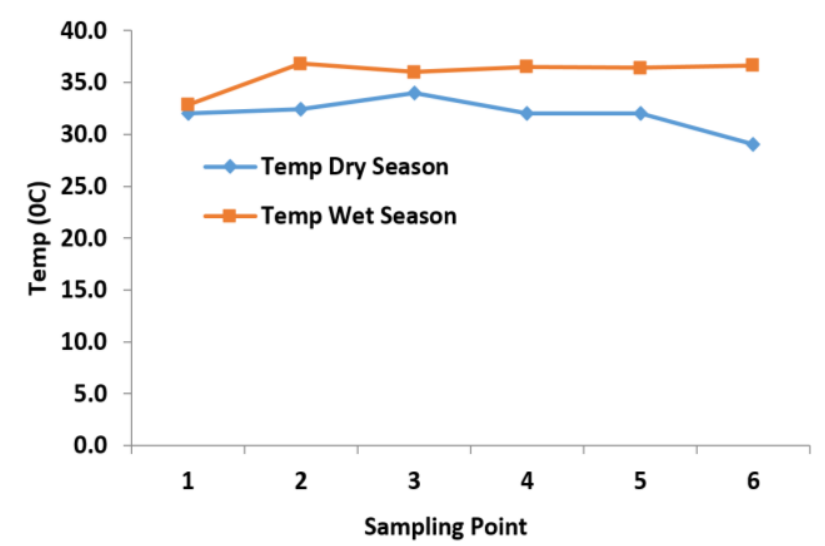

Figure 3: Variation in temperature $\left({ }^{\circ} \mathrm{C}\right)$

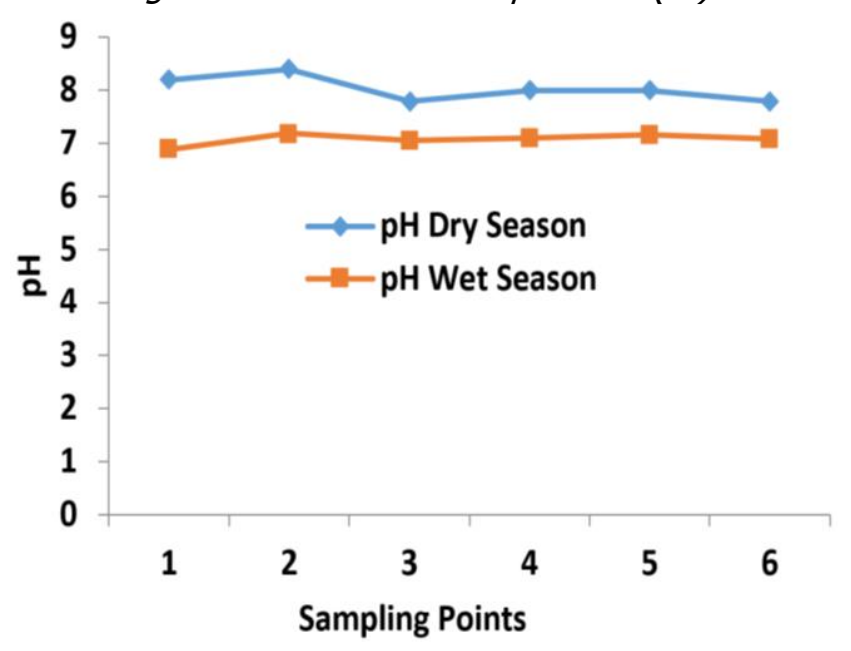

Figure 4: Variation in $\mathrm{pH}$

Vol. 39, No. 3, July 2020 
Table 2: Physicochemical analysis of effluent load discharged to Ngo River, Onyi River and effluent quality standards

\begin{tabular}{|c|c|c|c|c|c|c|}
\hline \multirow[t]{2}{*}{ Parameters } & \multicolumn{2}{|c|}{$\begin{array}{l}\text { Effluent outfall } \\
\text { concentration in dry } \\
\text { and wet season. Ngo } \\
\text { River }\end{array}$} & \multirow[t]{2}{*}{$\begin{array}{l}\text { Effluent outfall } \\
\text { concentration [8] } \\
\text { Onyi River }\end{array}$} & \multirow[t]{2}{*}{$\begin{array}{l}\text { River Effluents } \\
\text { discharge } \\
\text { guideline [15] }\end{array}$} & \multirow[t]{2}{*}{$\begin{array}{l}\text { Effluent } \\
\text { discharge into } \\
\text { water guideline } \\
{[16]}\end{array}$} & \multirow[t]{2}{*}{ Remarks } \\
\hline & Dry & Wet & & & & \\
\hline $\mathrm{pH}$ & 8.4 & 7.2 & $7.5-10.5$ & $6-9$ & $6-8$ & $\begin{array}{l}\text { Within } \\
\text { standards and } \\
\text { better than } \\
\text { Onyi river }\end{array}$ \\
\hline $\begin{array}{l}\text { Temperature } \\
{ }^{\circ} \mathrm{C}\end{array}$ & 33.5 & 37.5 & $24-34$ & $\begin{array}{l}<40 \text { within } 15 \\
\text { meter of } \\
\text { outfall }\end{array}$ & $20-35$ & $\begin{array}{l}\text { Both rivers are } \\
\text { within } \\
\text { standards }\end{array}$ \\
\hline $\mathrm{EC}(\mu \mathrm{s} / \mathrm{cm})$ & 100 & 128 & & & 1000 & $\begin{array}{l}\text { Within } \\
\text { standards }\end{array}$ \\
\hline TDS (mg/l) & 256 & 245 & $40-620$ & 2000 & 1200 & $\begin{array}{l}\text { Within } \\
\text { standards }\end{array}$ \\
\hline TSS (mg/l) & 225 & 260 & $20-1590$ & 30 & 100 & $\begin{array}{l}\text { Above } \\
\text { standards }\end{array}$ \\
\hline DO (mg/l) & 1.4 & 2.5 & $3.9-9.7$ & 7.5 & & $\begin{array}{l}\text { Below } \\
\text { standards }\end{array}$ \\
\hline BOD (mg/l) & 0.9 & 1.8 & $3.1-12.2$ & 30 & 50 & $\begin{array}{l}\text { Within } \\
\text { standards }\end{array}$ \\
\hline TP & 0.57 & 0.76 & & & & \\
\hline Nitrate $(\mathrm{mg} / \mathrm{l})$ & 22.0 & 25.8 & $68-395$ & 20 & & $\begin{array}{l}\text { Slightly above } \\
\text { standards }\end{array}$ \\
\hline COD (mg/l) & 1.8 & 3.6 & $42-170$ & 150 & 100 & $\begin{array}{l}\text { Within } \\
\text { standards }\end{array}$ \\
\hline $\begin{array}{l}\text { Sulphate } \\
(\mathrm{mg} / \mathrm{l})\end{array}$ & 63 & 78 & $1.35-10.1$ & 500 & 500 & $\begin{array}{l}\text { Within } \\
\text { standards }\end{array}$ \\
\hline $\begin{array}{l}\text { Chloride } \\
(\mathrm{mg} / \mathrm{l})\end{array}$ & 71 & 35.5 & $4.0-37.0$ & 600 & 500 & $\begin{array}{l}\text { Within } \\
\text { standards }\end{array}$ \\
\hline $\begin{array}{l}\text { Calcium } \\
(\mathrm{mg} / \mathrm{l})\end{array}$ & 60 & 20 & $12.8-58$ & 200 & 100 & $\begin{array}{l}\text { Within } \\
\text { standards }\end{array}$ \\
\hline $\begin{array}{l}\text { Magnesium } \\
(\mathrm{mg} / \mathrm{l})\end{array}$ & 100 & 40 & $5.1-22.8$ & 200 & 100 & $\begin{array}{l}\text { Within } \\
\text { standards }\end{array}$ \\
\hline $\begin{array}{l}\text { Total } \\
\text { Hardness }\end{array}$ & 160 & 60 & $34-153$ & & & \\
\hline $\begin{array}{l}\text { Turbidity } \\
\text { (NTU) }\end{array}$ & 52 & 189 & $7.5-804$ & 5 & & $\begin{array}{l}\text { Above } \\
\text { standards }\end{array}$ \\
\hline
\end{tabular}




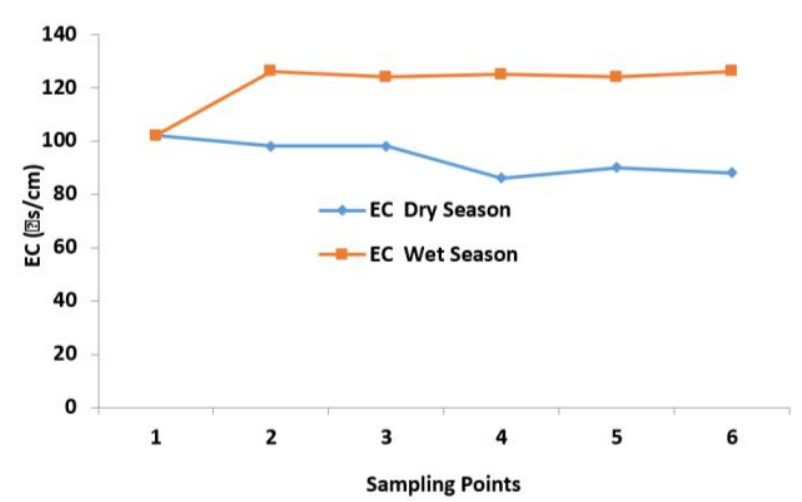

Figure 5: Variation in $E C(\mu \mathrm{s} / \mathrm{cm})$.

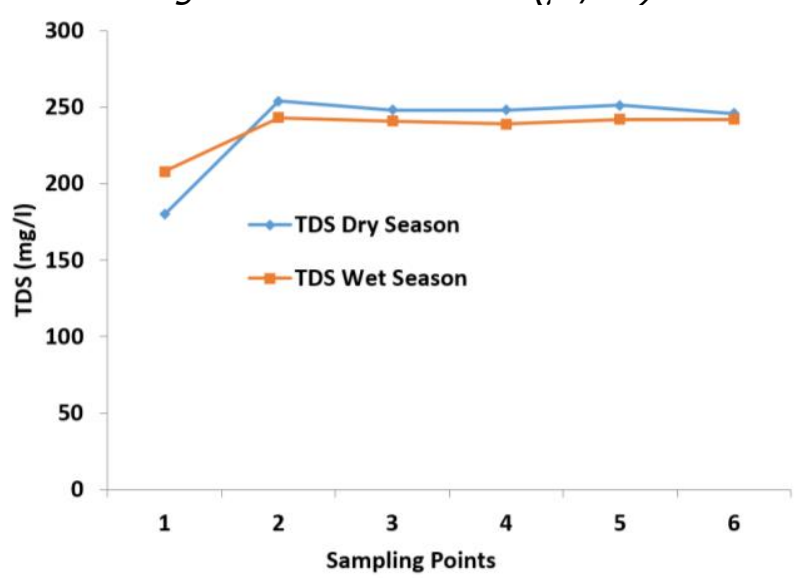

Figure 6: Variation in TDS ( $\mathrm{mg} / \mathrm{l})$.

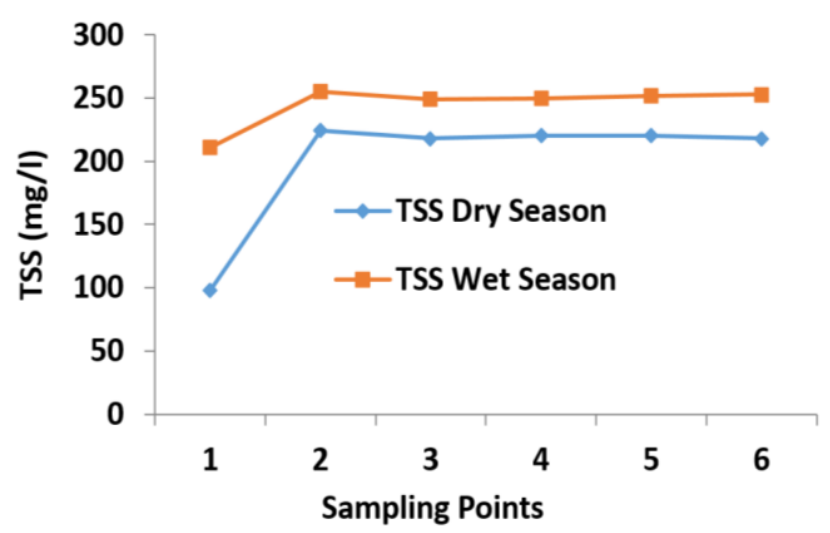

Figure 7: Variation in TSS (mg/l).

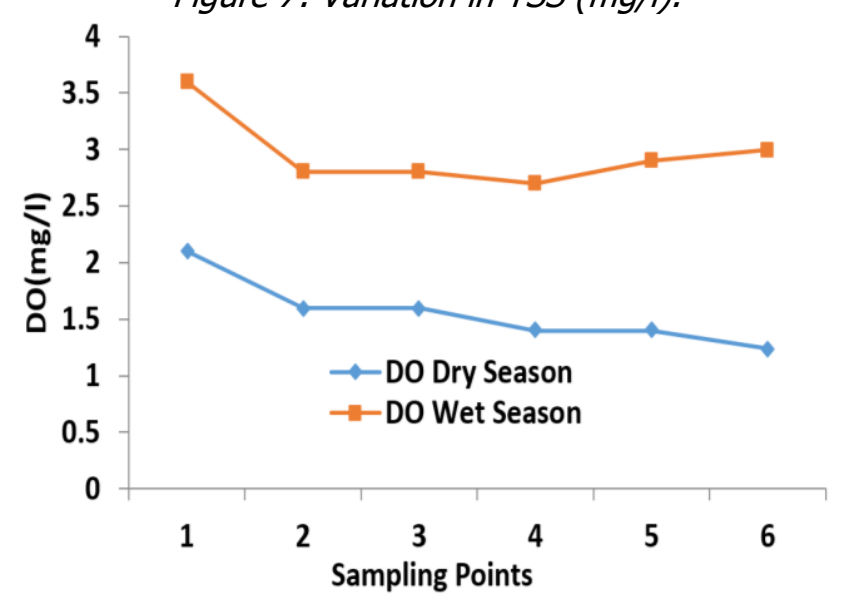

Figure 8: Variation in DO ( $\mathrm{mg} / \mathrm{l})$.

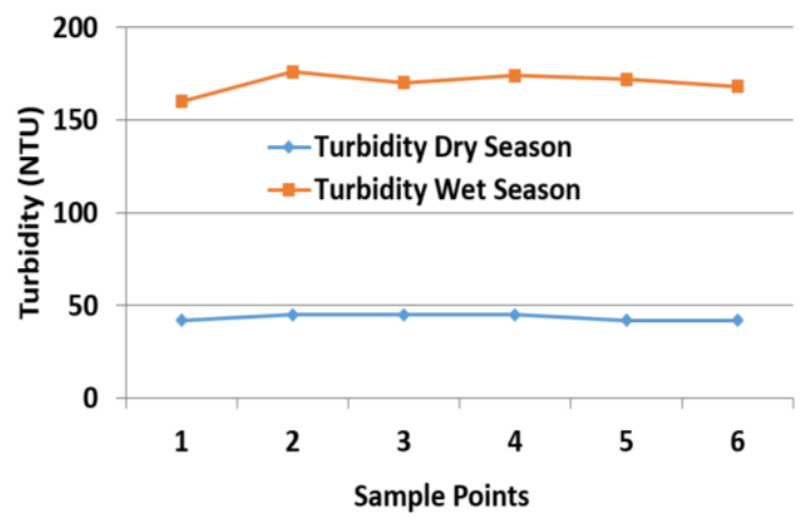

Figure 9: Variation in Turbidity (NTU)

\section{CONCLUSION}

Water of suitable quantity and quality is a prerequisite for significant socioeconomic development of any community. Physicochemical analysis of effluent outfall in Ngo River was assessed to ascertain its effect on the water quality of the River. The result obtained for dry and wet seasons showed most parameters to be within $[12,14,15]$ regulatory units, except DO, TSS, Nitrate, Turbidity which were above regulatory standards. This suggests relative treatment of the effluent, though is better compared to similar effluent discharged into Onyi River. The effect of the effluent along the $15 \mathrm{~km}$ stretch was better compared to similar study conducted a decade ago. However, there is need to reduce the TSS and turbidity to avoid the adverse effect it may have on the aquatic plants and organisms, the fishery and agricultural use capacity of the river. Hence, treatment of the effluent prior to discharge need to be improved to the FEPA permissible limits.

\section{REFERENCES}

[1] Akaniwor, J.O., Anosike, E.O. and Egwim, O. Effect of Indomie industrial effluent discharge on microbial properties of new Calabar River, Sci Res Essays 2 (1): 001-005, 2007.

[2] Fu, L. J., Stares, R. E., and Stahy, R. G., Jr.. Assessing acute toxicities of pre and post treatment industrial wastewaters with Hydra attenata. A comparative study of toxicity with the fathead minnows, phimephales, promelas, Environ. Toxicol. Chem., 13: 563-569, 1994.

[3] Adejoh, L.P. Assessment of heavy metal contamination of soil and cassava plants within the vicinity of a cement of a cement factory in north central Nigeria. Advances in Applied Science Research, 7, 20, 27, 2016 
[4] Meme, F.K; and Nwadukwe, F.O. Impact of Cement Factory Waste Water on the Heavy metal contents of a typical Low-Latitude Stream in North Central Nigeria, Chemistry and Materials Research. Vol. 8 No.5 2016.

[5] Oyegun, R.O. Environmental Problems of Water Resource Development. A Geographical Perspective in Ofomata, G.E. and Phil-Eze, P.O. (eds) Geographical Perspectives on Environmental Problems and Management in Nigeria. Enugu: Jamoe Publishers (Nig.), 2001

[6] Eze, B.E. and Abua, M.A. Water Resources Management. Calabar: Ushie Printers and Publishing Co. Ltd, 2003.

[7] Yadav, A., Rajhans, K.P., Ramteke, S., Sahu, B.L., Patel, K.S. and Biazhev, B. Contamination of industrial waste water in central India. Journal of Environmental Protection, 7. 72-81, 2016.

[8] Ipeaiyeda, A.R. and Obaje, G.M. Impact of cement effluent on water quality of rivers: A case study of Onyi River at Obajana, Nigeria, Cogent Environmental Science, 3: 1319102, 2017.

[9] Terhemen, A and Egila JN Heavy Metals in sediments of some inland waters adjacent to Benue Cement Company Plc, Benue State, Nigeria. African Journal of Environmental Pollution Health 6 (1) 1 - 6, 2008

[10] Mile, I.I, Amonum, J.I and Mile, T.J (2014) Environmental pollution status of surface water around Dangote cement company complex Gboko, Benue State, Nigeria. Manuscript accepted in 2013. Asian Journal of Advanced Basic Science, 2014

[11] APHA Standard Methods for Examination of water and Wastewaters $20^{\text {th }}$ ed. American Public
Health Association, APHA, Washington D.C. 1134 PP, 1999.

[12] World Health Organisation. Guidelines for Drinking Water Quality: Incorporating first addendum (Vol. 1, Recommendations 2). Geneva: Author, 2006.

[13] USEPA. Environment fact sheet Management standards proposed for cement kiln dust waste. Retrieved October 20 ${ }^{\text {th }}$ 2014, from http//www.epa.gov//fed.gstr/EPA-AIR/199/ some/Day.14/012893.htm., 2014

[14] National Environment Standards and Regulations Enforcement Agency. (2011). Federal Republic of Nigeria Official Gazette, Nigeria; Lagos. 98, 693727. Retrieved March 20, 2017, from http://extwprlegs1.fao.org/docs/pdf/ nig145947.pdf

[15] Federal Environmental Protection Agency (FEPA). Guideline to Standards for Environmental Pollution Control in Nigeria. FG Press Lagos Nigeria. Pp 238, 1991.

[16] Mackie, A. L., and Walsh, M. E. Bench-scale study of active mine water treatment using cement kiln dust (CKD) as a neutralization agent. Water Research, 46, 327-334, 2012

[17] Karikari, A. Y., and Ansa-Asare, O. D. Physicochemical and microbial water quality assessment of Densu River of Ghana. West African Journal of Applied Ecology, 10(1), 2006.

[18] Gaharwar, A. S., Gaurav, N., Singh, A. P., Singh, H., \& Gariya, B. A review article on manufacturing process of cement, environment attributes, topography and climatological data station: 1MD, Sidhi M. P. Journal of Medicinal Plants Studies, 4, 47-53, 2016. 